\title{
ПУБЛИЧНАЯ ОТВЕТСТВЕННОСТЬ ЗА НАРУШЕНИЕ АВТОРСКИХ ПРАВ
}

\begin{abstract}
Аннотация. Интеллектуальная собственность является важной составляющей как духовной, так и экономической жизни общества, в связи с этим государство обязано обеспечить всестороннюю защиту прав на интеллектуальную собственность. Предметом рассмотрения данной статьи являлись вопросы публичной ответственности за нарушение авторских прав. В то время как, целью написания работы являлось проведение анализа смежных составов уголовных преступлений и административных правонарушений в указанной срере, а также выявление пробелов законодательного регулирования публичной ответственности за нарушение авторских прав. При написании работы применялся метод анализа, аналогии, моделирования, изучения нормативно-правовых норм и правоприменительной практики. В результате были выявлен ряд противоправных действий, нарушающие авторские права, но не подпадающие под нормы об уголовной или административной ответственности. Автором предлагаются изменения в Кодекс Российской Федерации об административных правонарушениях, позволяющие обеспечить всеобъемлющую защиту авторских прав по средствам публичного права.
\end{abstract}

Ключевые слова: публичная ответственность, административная ответственность, уголовная ответственность, смежные составы правонарушений, интеллектуальная собственность, авторские права, плагиат, изменения в законодательстве, исключительные права, правонарушение.

Review. Intellectual property is an important component of spiritual and economic life of society, in this regard the state must ensure the comprehensive protection of intellectual property rights. The subject of this article is the question of public liability for copyright infringement. The purpose of the article is to analyze the criminal offenses and administrative offenses in this sphere and to reveal the deficiencies of legal regulation of public liability for copyright infringement. The work uses the methods of analysis, analogy, modeling, study of legal norms and law-enforcement practice. In the result the author identifies a number of illegal actions which violate copyrights but can't be regulated by the norms of legal or criminal legislation. The author proposes the amendments to the Code of Administrative Offences of the Russian Federation which can provide the comprehensive copyright protection by means of public law.

Keywords: plagiarism, copyright, intellectual property, related offenses, criminal liability, administrative liability, public liability, changes in legislation, exclusive rights, offence.

И нтеллектуальная собственность укрепляет позиции в деятельности современного государства. Российская Федерация начала глобальную реформу законодательства об интеллектуальной собственности в 2008 году, путем принятия четвертой части Гражданского кодекса Российской Федерации [1], данная реформа продолжается и сегодня [2]. Пристальное внимание к развитию инновационной деятельности связано, прежде всего, с мировыми экономическими тенденциями, которые ложатся в основу социальноэкономического развития Российской Федерации: «Динамика курсов акций и цен на сырьевые товары повышают актуальность перехода России на инновационный тип экономического развития...» [3].

Наряду со стимулированием интеллектуальной и инновационной активности, одной из важных задач современного государства является защита прав интеллектуальной собственности. Согласно п.2 ст. 1225 Гражданского кодекса: «интеллектуальная собственность охраняется законом» $[1$, п.2 ст 1225]. Под «законной» охраной понимается как защита посредствам частного права, так и по средствам публичного права. В настоящий момент публичная ответственность за нарушение прав интеллектуальной собственности устанавливается в уголовном и административном законодательстве. Так, статьей 7.12 Кодекса об административных правонарушениях РФ устанавливается ответственность за нарушение авторских и патентных прав, статьей 14.10 - ответственность за незаконное использование товарного знака, знака обслуживания, наименования места происхождения товара или сходных с ними обозначений для однородных товаров. Ст. 146 Уголовного кодекса РФ устанавливается ответственность за нарушение авторских 
и смежных прав, ст. 147 устанавливает уголовную ответственность за нарушение изобретательских и патентных прав, ст. 180 Уголовного кодекса РФ ответственность за незаконное использование средств индивидуализации товаров (работ, услуг). Проведем сравнительный анализ указанных составов для выявления сути толкуемых правовых норм в их взаимосвязи.

Рассмотрим, какие возможности предоставляет публичное право для охраны авторских прав. Так, квалифицирующим признаком административного правонарушения, предусмотренного ч.1 ст. 7.12 КоАП РФ: «Ввоз, продажа, сдача в прокат или иное незаконное использование экземпляров произведений или фонограмм в целях извлечения дохода в случаях, если экземпляры произведений или фонограмм являются контрафактными в соответствии с законодательством Российской Федерации», является цель - извлечение дохода, в то время как цель извлечения дохода не является квалифицирующим признаком уголовного преступления, предусмотренного ч.1 ст. 146 [4]. Данный состав предусматривает ответственность за присвоение авторства, повлекший для автора или иного правообладателя крупный ущерб. Нам не удалось найти практику применения указанного состава уголовного преступления. Полагаем, что данное обстоятельство связано с неопределенностью применения ч. 1 ст. 146, которое, по нашему мнению, обусловлено материальной конструкцией нормы, в виде указания на крупный ущерб. Согласно ст. 1255 Гражданского кодекса под авторскими правами понимаются: «интеллектуальные права на произведения науки, литературы и искусства» [1, ст. 1225]. В свою очередь, интеллектуальные права состоят из личных неимущественных прав, исключительных прав и иных прав [1, ст. 1226], при этом только исключительное право является имущественным [1, ст. 1226]. Действия, предусмотренные ч.1 ст. 146 Уголовного кодекса Российской Федерации и составляющие плагиат, нарушают право авторства, предусмотренное ст. 1267 Гражданского кодекса РФ, относящееся к личным неимущественным правам автора. Возникает закономерный вопрос: каким образом, присваивая авторство (плагиат), можно нанести имущественный ущерб автору? На наш взгляд, данный ущерб заключается в нарушении исключительного права автора. Также следует обратить внимание на тот факт, что ч. 1 ст. 146 УК РФ предусматривает причинения ущерба «иному правообладателю» $[4$, ч.1 ст. 146], а поскольку отчуждению и передаче под- лежат лишь исключительные права [1, ст. 1228], подразумевается нарушение исключительного права. Данная позиция прослеживается и в постановлении Пленума Верховного Суда[5]. Суд отмечает: «При установлении факта нарушения авторских прав путем присвоения авторства (плагиата), предусмотренного частью 1 статьи 146 УК РФ, суду надлежит иметь в виду, что указанное деяние может состоять, в частности, в объявлении себя автором чужого произведения, выпуске чужого произведения (в полном объеме или частично) под своим именем, издании под своим именем произведения, созданного в соавторстве с другими лицами, без указания их имени» [5, п.3]. Все из вышеперечисленного, за исключением «объявление себя автором чужого произведения», влечет нарушение исключительных прав автора или иного правообладателя. Открытым остается вопрос, каким образом, не нарушая исключительного права, а лишь объявив себя автором чужого произведения можно причинить крупный ущерб?

Норма о плагиате отсутствует в законодательстве об административных правонарушениях, мы полагаем, что введение административной ответственности за схожее правонарушение нецелесообразно. Рассматривая возможность установления административного наказания за плагиат, не подпадающего под признаки административного правонарушения, указанного в ст. 7.12 КоАП РФ, мы приходим к выводу, что данная необходимость отсутствует. Предположим, что административное законодательство предусматривает ответственность за присвоение авторства без причинения крупного ущерба правообладателю, тогда состав такого правонарушения возникает лишь в случае, если деликвент публично объявит себя автором чужого произведения, при этом не предпримет действий, нарушающих исключительное право, таких как: публикация или иное распространение произведения от своего имени. В противном случае, действия нарушителя можно будет квалифицировать по ч.1 ст. 7.12 КоАП РФ. Действия по публичному объявлению себя автором чужого произведения без дальнейшего нарушения исключительных прав правообладателя, на наш взгляд, нельзя признать общественновредными в силу их малозначительности, а значит вводить подобный состав административного правонарушения - нецелесообразно.

Ч.2 ст. 146 Уголовного кодекса РФ устанавливает уголовную ответственность за нарушение исключительных прав, которое выражается в «не- 
законном использовании объектов авторского права или смежных прав, а равно приобретении, хранении, перевозке контрафактных экземпляров произведений или фонограмм в целях сбыта, совершенные в крупном размере» [4, ч.2 ст. 146]. Сравнивая гипотезу ч.1 ст. 7.12 КоАП РФ и ч.2 ст. 146 УК РФ, следует отметить схожесть юридической конструкции норм, но в то же время наблюдается некоторая разобщённость в использовании терминов и подхода к формулированию цели совершения деликта. Так, КоАП РФ устанавливает ответственность за ввоз, продажу, сдачу в прокат или иное незаконное использование экземпляров произведений, при этом указание на ввоз, продажу и сдачу в прокат носит уточняющий характер, поскольку все вышеперечисленные способы подпадают под понятие иного незаконного использования экземпляров произведения. Уголовный кодекс устанавливает ответственность за «незаконное использование объектов авторского права или смежных прав, а равно приобретение, хранение, перевозка контрафактных экземпляров произведений или фонограмм». Гипотеза уголовной нормы выстроена аналогичным образом, устанавливаются действия, выражающие объективную сторону в общем виде, - незаконное использование объектов авторских прав, которые уточняются указаниями на непосредственные способы незаконного использования - приобретение, хранение, перевозка экземпляров произведений.

Указанные составы уголовного и административного правонарушения разграничиваются по ущербу. При этом, деяние считается уголовным, если правообладателю был причинен крупный ущерб, который составляет сто тысяч рублей. Анализируя объективную сторону приведенных выше составов, в первую очередь, следует отметить, что «использованием произведения независимо от того, совершаются ли соответствующие действия в целях извлечения прибыли или без такой цели, считается, в частности: импорт оригинала или экземпляров произведения в целях распространения» [1, п.п.4 п.2 ст. 1270], то есть, незаконный ввоз на территорию Российской Федерации объектов авторского права, а равно контрафактных экземпляров, является незаконным использованием и образует состав преступления. Выявление фактов незаконного ввоза относится к компетенции Федеральной таможенной службы [6]. Поскольку и ч.1 ст. 7.12 КоАП РФ и ч.2 ст. 146 УК РФ содержат указание на незаконное использование с уточняющим перечислением некоторых видов незаконно- го использования, мы приходим к выводу, что любые действия, наущающие исключительные права, выразившиеся в незаконном использовании любым способом, могут быть квалифицированы как уголовное преступление или административное правонарушение, в зависимости от суммы причинённого ущерба.

Субъективная сторона административного правонарушения и субъективная сторона уголовного преступления, нарушающих исключительные права на произведение выражается в прямом умысле. Важно отметить, что субъективная сторона административного правонарушения дополнена целью - извлечением дохода, в то время как цель не является квалифицирующим признаком преступления. Складывается ситуация, при которой умышленные действия, выразившиеся в незаконном использовании произведений, экземпляров произведений, не направленные на извлечение дохода и не повлекшие причинения правообладателю ущерба свыше ста тысяч рублей не подлежат квалификации как административное правонарушение или уголовное преступление.

Необходимо ли введение административной ответственности за действия, повлекшие нарушение исключительных прав на произведения, совершенные без цели извлечения дохода? Для ответа на данный вопрос рассмотрим следующее правонарушение: лицо незаконно размещает в сети «Интернет» литературное произведение, допуская его бесплатное скачивание. Количество скачиваний, с учетом розничной цены экземпляра произведения, не повлекло причинения крупного ущерба правообладателю. Как следствие, наступление уголовной ответственности в данном случае невозможно. Вопрос о корыстной цели (извлечение дохода) более сложный и имеет два аспекта. Во-первых, получал ли нарушитель денежные средства непосредственно за доступ к экземпляру произведения. Во-вторых, получал ли нарушитель косвенный доход от размещения произведения, например, путем размещения рекламы на странице сайта. Если в первом случае можно определенно утверждать об отсутствии корыстной цели (отсутствие платы за доступ к экземпляру, отсутствие рекламных материалов, размещенных на платной основе), то втором случае следует определить - является ли размещение рекламы на странице с незаконно размещенным экземпляром произведения извлечением дохода в понимании ст. 7.12 КоАП РФ? Полагаем, что в случае неправомерного размещения авторского произведения на 
странице в информационно-телекоммуникационной сети «Интернет», совместно с предоставлением оплачиваемых услуг по размещению на данной странице рекламных материалов, лицо, неправомерно разместившее такие материалы, не может быть привлечено к административной ответственности, поскольку невозможно доподлинно установить умысел на извлечение дохода. Также можно провести аналогию с решением научноконсультационного совета при Суде по интеллектуальным правам по вопросу ответственности информационных посредников: «Вместе с тем возможным видится подход, согласно которому лицо, которое получает вознаграждение не от предоставления возможности размещения материалов или информации либо предоставления возможности доступа к материалу в сети Интернет, не подпадает под само определение информационного посредника» [7].

Описанные действия являются достаточно распространёнными, в связи с этим, возникает си- туация, при которой в законодательстве не установлена публичная ответственность за нарушение авторских прав, совершенное без цели извлечения дохода и не повлёкшее крупного ущерба правообладателю. Возможным видится подход установления административной ответственности за указанные действия в случае нарушения авторских прав на несколько объектов, к примеру, не менее пяти, что подтверждает систематичность нарушения авторских прав, с причинением правообладателю определенного ущерба. Для установления порога такого ущерба необходимо провести дополнительное исследование экономических аспектов оборота объектов авторского права.

Кроме того, не следует забыть, что правообладатель имеет возможность прибегнуть к защите с помощью частного права, однако, имеющийся пробел в нормах публичного права необходимо привести в соответствии со статьей 1225 Гражданского кодекса, с целью обеспечения всеобъемлющей охраны законом интеллектуальной собственности.

\section{Библиография:}

1. Гражданский кодекс Российской Федерации (часть четвертая) от 18.12.2006 № 230-Ф3 (ред. от 31.12.2014) // СЗ РФ. 2006. № 52 (1 ч.). Ст. 5496.

2. Федеральный закон от 12.03.2014 № 35-Ф3 «0 внесении изменений в части первую, вторую и четвертую Гражданского кодекса Российской Федерации и отдельные законодательные акты Российской Федерации» // СЗ РФ. 2014. № 11. Ст. 1100.

3. Распоряжение Правительства РФ от 17.11.2008 № 1662-р (ред. от 08.08.2009) «0 Концепции долгосрочного социально-экономического развития Российской Федерации на период до 2020 года» // СЗ РФ. 2008. № 47. Ст. 5489.

4. Уголовный кодекс Российской Федерации от 13.06.1996 № 63-Ф3 (ред. от 08.06.2015) // СЗ РФ. 1996. № 25. Ст. 2954.

5. Постановление Пленума Верховного Суда РФ от 26.04.2007 № 14 «0 практике рассмотрения судами уголовных дел о нарушении авторских, смежных, изобретательских и патентных прав, а также о незаконном использовании товарного знака» // РГ. 2007. № 95.

6. Агамагомедова С.А. Порядок действий таможенных органов РФ по защите прав на объекты интеллектуальной собственности и его оптимизация в современных условиях // Административное и муниципальное право. 2014. № 6. С. $559-568$.

7. Справка. Ответственность информационного посредника. Использование товарных знаков в информационнотелекоммуникационной сети Интернет [Официальный сайт Суда по интеллектуальным правам] // URL: http:// ipc.arbitr.ru/node/13619 (дата обращения 01.08.2015).

8. Кодекс Российской Федерации об административных правонарушениях от 30.12.2001 № 195-ФЗ (ред. от 29.06.2015) // СЗ РФ. 2002. № 1 (ч.1). Ст. 1.

9. Чуковская Е.Э. Распространение произведений в сети Интернет в национальном и международном законодательстве // Журнал зарубежного законодательства и сравнительного правоведения / Journal of foreighn legislation and comparative law. 2013. №2. C. 251-270.

10. Маркова О.В. Перспективы правовой защиты интеллектуальной собственности и способы укрепления устойчивого элемента системы правовой защиты интеллектуальной собственности // Политика и Общество. 2012. №6. C. $101-106$.

\section{References (transliterated):}

1. Grazhdanskii kodeks Rossiiskoi Federatsii (chast' chetvertaya) ot 18.12.2006 № 230-FZ (red. ot 31.12.2014) // SZ RF. 2006. № 52 (1 ch.). St. 5496.

2. Federal'nyi zakon ot 12.03.2014 № 35-FZ «0 vnesenii izmenenii v chasti pervuyu, vtoruyu i chetvertuyu Grazhdanskogo kodeksa Rossiiskoi Federatsii i otdel'nye zakonodatel'nye akty Rossiiskoi Federatsii» // SZ RF. 2014. № 11. St. 1100. 
3. Rasporyazhenie Pravitel'stva RF ot 17.11.2008 № 1662-r (red. ot 08.08.2009) «O Kontseptsii dolgosrochnogo sotsial'noekonomicheskogo razvitiya Rossiiskoi Federatsii na period do 2020 goda» // SZ RF. 2008. № 47. St. 5489.

4. Ugolovnyi kodeks Rossiiskoi Federatsii ot 13.06.1996 № 63-FZ (red. ot 08.06.2015) // SZ RF. 1996. № 25. St. 2954.

5. Postanovlenie Plenuma Verkhovnogo Suda RF ot 26.04.2007 № 14 «O praktike rassmotreniya sudami ugolovnykh del o narushenii avtorskikh, smezhnykh, izobretatel'skikh i patentnykh prav, a takzhe o nezakonnom ispol'zovanii tovarnogo znaka» // RG. 2007. № 95.

6. Agamagomedova S.A. Poryadok deistvii tamozhennykh organov RF po zashchite prav na ob"ekty intellektual'noi sobstvennosti i ego optimizatsiya v sovremennykh usloviyakh // Administrativnoe i munitsipal'noe pravo. 2014 . № 6. S. 559 - 568.

7. Spravka. Otvetstvennost' informatsionnogo posrednika. Ispol'zovanie tovarnykh znakov $\mathrm{v}$ informatsionnotelekommunikatsionnoi seti Internet [Ofitsial'nyi sait Suda po intellektual'nym pravam] // URL: http://ipc.arbitr.ru/ node/13619 (data obrashcheniya 01.08.2015).

8. Kodeks Rossiiskoi Federatsii ob administrativnykh pravonarusheniyakh ot 30.12.2001 № 195-FZ (red. ot 29.06.2015) // SZ RF. 2002. № 1 (ch.1). St. 1.

9. Chukovskaya E.E. Rasprostranenie proizvedenii v seti Internet v natsional'nom i mezhdunarodnom zakonodatel'stve // Zhurnal zarubezhnogo zakonodatel'stva i sravnitel'nogo pravovedeniya / Journal of foreighn legislation and comparative law. 2013. №2. C. 251-270.

10. Markova O.V. Perspektivy pravovoi zashchity intellektual'noi sobstvennosti i sposoby ukrepleniya ustoichivogo elementa sistemy pravovoi zashchity intellektual'noi sobstvennosti // Politika i Obshchestvo. 2012. №6. C. 101 - 106. 